doi: 10.12957/childphilo.2017.26122

\title{
myth and play in plato's phaedrus
}

\author{
noa 1 ayalon ${ }^{1}$ \\ boston university - israel
}

abstract

Plato's Phaedrus is a famously intriguing dialogue. It employs a wide range of writing styles, such as myth, dialectic discussion, rehearsed and spontaneous speeches, and lines of verse. It makes a sharp transition from speech-making and storytelling, which make up the first half of the dialogue and deal with love, to dialectical discussion and an analysis of rhetoric in its second half. Socrates himself claims erotic madness is man's greatest blessing. How seriously can we take such a strange dialogue? How serious can we be regarding its message? In this article I will suggest a playful reading of the Phaedrus. Not only does the notion of play (paidia) feature prominently in several key passages of the text, but there is also an atmosphere of playfulness throughout the drama of the dialogue, which takes place on the banks of the river Ilisus. This is a philosophical playfulness which is not divorced from childish playfulness. As we will see, the philosopher and the child have much in common, and their shared attributes figure in the Phaedrus: the child is commonly perceived to be irrational, but irrationality in this dialogue is a blessing, according to Socrates; play is childish, but philosophy, mythmaking and writing are a form of play; and children are inherently learners - which is also what the philosopher ultimately aims at. The argument presented in this paper is based on a textual analysis of the word "play" (in its various forms) in the Phaedrus. The substantial link made between play, myth and writing will be shown to have important implications on Plato's concept of philosophy as play, as well as on his view of the philosopher as child-like.

keywords: ancient philosophy; phaedrus; myth; play

resumen

\section{mito y juego en el fedro de platón}

El Fedro de Platón es un diálogo afamadamente intrigante. Emplea una amplia variedad de estilos de escritura, como el mito, la discusión dialéctica, discursos ensayados y espontáneos, y líneas de verso. Realiza una nítida transición desde la discursiva y la narrativa, que constituyen la primera mitad del diálogo y lidian con el amor, hasta la discusión dialéctica y el análisis de la retórica en su segunda mitad. El propio Sócrates sostiene que la locura erótica es la mayor bendición humana. ¿Cuán seriamente podemos tomar un diálogo tan extraño? ¿Qué tan serios podemos ser en relación a su mensaje? En este artículo voy a sugerir una lectura divertida del Fedro. Esta noción de juego (paidia) no sólo aparece prominentemente en varios pasajes clave del texto, sino que además hay una atmosfera de carácter lúdico a lo largo del drama del diálogo, que tiene lugar en las orillas del río Ilisus. Éste es un juego filosófico que no está separado del juego infantil. Como veremos, el filósofo y el niño tienen mucho en común, y sus atributos compartidos aparecen en el Fedro: el niño es comúnmente percibido como alguien irracional, pero la irracionalidad es en este diálogo una bendición,

${ }^{1}$ E-mail: nlayalon@bu.edu 
según Sócrates; el juego es infantil, pero la filosofía, la creación de mitos y la escritura son una forma de juego; y los niños se caracterizan inherentemente por aprender - que es también en definitiva aquello a lo que el filósofo apunta. El argumento presentado en este artículo está basado en un análisis textual de la palabra "juego" (en sus varias formas) en el Fedro. Se mostrará cómo el vínculo sustancial entre juego, mito y escritura tiene importantes implicaciones para el concepto platónico de la filosofía como juego, y también en su visión del filósofo como un niño.

palabras clave: filosofía antigua; fedro; mito; juego.

resumo

\section{mito e brincadeira no fedro de platão}

O Fedro de Platão é um diálogo de fama intrigante. Possui uma ampla variedade de estilos de escrita, como o mito, a discussão dialética, discursos ensaiados e espontâneos e linhas de verso. Realiza uma nítida transição desde o discurso à narração, que constituem a primeira metade do diálogo e lidam com o amor, até a discussão dialética e a análise da retórica em sua segunda metade. O próprio Sócrates sustenta que a loucura erótica é a maior bênção humana. Quão seriamente podemos considerar um diálogo tão estranho? Que tão sérios podemos ser em relação a sua mensagem? Neste artigo irei sugerir uma leitura divertida do Fedro. Essa noção de brincadeira (paidia) não só aparece proeminentemente em várias passagens chave do texto, mas também, além disso, há uma atmosfera de caráter lúdico ao longo do drama do diálogo, que acontece nas margens do rio Ilisus. Essa é uma ludicidade filosófica que não se encontra separada da ludicidade infantil. Como veremos, o filósofo e a criança têm muito em comum, e seus atributos compartilhados aparecem no Fedro: a criança é comumente percebida como alguém irracional, mas a irracionalidade é neste diálogo uma bênção, de acordo com Sócrates; a brincadeira é infantil, mas a filosofia, a criação de mitos e a escrita são uma forma de brincadeira; e as crianças se caracterizam inerentemente por serem aprendizes - que também é aquilo ao que o filósofo aspira. O argumento apresentado neste artigo está baseado em uma análise textual da palavra "brincadeira" (em suas várias formas) no Fedro. Se mostrará como o vínculo substancial entre brincadeira, mito e escrita tem implicações importantes no conceito platônico da filosofia como um jogo, assim como também em sua visão do filósofo como uma criança.

palavras-chave: filosofia antiga; fedro; mito; brincadeira. 
myth and play in plato's phaedrus

Plato's Phaedrus is a unique dialogue. It tells the story of a conversation Socrates once had with his friend Phaedrus, while out on a walk in the country outside of Athen's walls. It is rare for readers of Plato to envision Socrates out of the city; stranger still to read of his enjoyment of the pastoral. The dialogue's frame is, in a way, compatible with the strangeness of the dialogue's content. Some commentators argue that it is about Eros, others claim it is about rhetoric.

In the Phaedrus, Plato subtly weaves together pairs of concepts which seem dichotomous. Myth and dialectic, rationality and madness, play and seriousness -- all appear, at first glance, to be mutually exclusive. The dialogue's structure itself is "split" down the middle, famously transitioning from speech-making to dialectical conversation. The first half of the dialogue is made up of a speech by the orator Lysias (read aloud by Phaedrus at Socrates' bidding), a speech by Socrates which follows Lysias' theme and style, and a second speech by Socrates, the Palinode, a compensation to the gods for Socrates' unphilosophical, immoral first attempt (in which Socrates, divinely inspired, tells the myth of the disembodied soul as a charioteer and two horses). The second half of the dialogue is a dialectical discussion of the nature of rhetoric and a detailed analysis of the speeches given earlier.

The seemingly dichotomous pairs of myth and dialectic, madness and philosophy, as well as the disunity of the text as a whole, are conspicuous and puzzling. In this paper, two of these pairs of concepts (play and seriousness, myth and dialectic) will be examined. The textual references to play (paidia) and playing (paizein) will be the basis of the study. It will be shown that Plato repeatedly refers to what Socrates and Phaedrus are doing by the river Ilisus, which seems very much to be a serious philosophical conversation, as play. Plato is implying that philosophy as it is practiced in everyday life, through conversation with others and through reading and writing, is a form of play. 
In the Phaedrus (and elsewhere in Plato's dialogues), the practice of mythmaking is found to be tied up with play. Myth is integrated into the dialogue at some of its most important parts. And although myth is presented quite clearly as a mode of discourse which is far from being wholly serious, the myths of the Phaedrus (as do myths of other dialogues) make important philosophical points. The myth of the Palinode, for example, presents central ideas such as the tripartite division of the soul, the soul's perception of Forms, recollection and the innateness of true knowledge, and the function of erotic relations in education. On one hand, these theories cannot really be taken at face value, because they are presented in a framework that Plato himself demands us to be suspicious of -- the ideas are unargued for and in a way unverifiable (how can we be sure of what happens after death?). ${ }^{2}$ On the other hand, the myth of the Palinode serves as the basis for the dialectical discussion of the second half of the dialogue. Obviously there was something in it worthwhile, other than a pretty story. I will argue that myth-making is a form of philosophical playfulness that Plato presents, through Socrates' actions, as vitally important and constructive for the most serious type of philosophizing man can hope for.

The first part of this paper will follow the textual appearances of the word "play" in the Phaedrus, as well as the dramatic situations which might also be construed as play. The second part ties the concepts of play and myth-making (or storytelling), in the Phaedrus and beyond. The third is a brief discussion of the links Plato makes between play, myth and writing, and the effect this might have on the interpretation of the dialogue as a whole.

\section{i. play in the phaedrus}

The Phaedrus opens with Socrates meeting Phaedrus near the city's walls, and their subsequent exit to the countryside. Phaedrus has just left the company of Lysias, the famous speech-writer, and he is trying to get Socrates to listen to his recitation of

\footnotetext{
${ }^{2}$ Commentators such as Luc Brisson and Daniel Werner claim that myths have no direct relation to philosophical truth at all. Their arguments will be discussed below.
} 
a speech he is infatuated with. It is a discourse meant to convince a beautiful young boy to favor a non-lover rather than a lover. The two men's conversation is quite playful. After Phaedrus is accused by Socrates that he is "playing coy" (228c2), the former agrees to recite the speech as best he can. Socrates won't have it - he exposes Phaedrus' manipulation by demanding he reveal what's under his cloak. It is, of course, the scroll of the written speech.

The game Socrates and Phaedrus are playing, which is a also a mimicry of erotic relations and pursuit, has them cast in roles that don't necessarily fit their age or social standing (Phaedrus is probably about forty, and Socrates more than a decade his senior). ${ }^{3}$ Moreover, it seems that this is a game Socrates isn't entirely willing to participate in. His disruption of Phaedrus' manipulative banter is initiated with strong words that serve to expose Phaedrus as savvy (a "player"): “Oh, Phaedrus, if I don't know my Phaedrus I must be forgetting who I am myself -- and neither is the case. I know very well that he did not hear Lysias' speech only once... he took the book himself and pored over the parts he liked best... [then,] running into a man who is sick with passion for hearing speeches... he was filled with delight..." (228a5-b7)4. Phaedrus holds the scroll in his left hand; in the speeches to come we will learn that there is a left-handed, bad sort of eros. Like Lysias' speech and the erotic practice he condones, the game Phaedrus is trying to lead is a left-handed game, different from the games Socrates will be happy to play during the rest of the dialogue.

Indeed, the word paidia (meaning a playful thing or a game) only first appears just as Phaedrus and Socrates are fully and consciously cooperative. As soon as they agree that Phaedrus will read Socrates the scroll in his possession, and find a pleasant place to sit and read, the idea of play is brought up (and it is tied up with the issue of myth). Phaedrus asks Socrates if he thinks somewhere nearby is the spot where Boreas the wind-god abducted Oreithyia from. Socrates agrees that's how the story

\footnotetext{
${ }^{3}$ On the role-playing in the prologue and the dramatic date, see Griswold (1986), pp.28-33; Gill (2012), p. xviii..

${ }^{4}$ All translations of the Phaedrus are by Nehamas and Woodruff (1997), unless noted otherwise.
} 
goes. Phaedrus asks: "Could this be the very spot? The stream is lovely, pure and clear: just right for girls to be playing (paizein) nearby" (229b6). The setup of the dialogue, it seems, is linked with an invitation for play. The insertion of the idea of play into the nature of the scenery foreshadows the return of the concept at important points in the dialogue ${ }^{5}$.

Socrates picks up on this idea of play and incorporates it in his reply, producing a unique version of the myth at hand: "...a gust of the North Wind blew [Oreithyia] over the rocks where she was playing (paizousan) with Pharmaceia" (229c6). This initial link between play and pharmaceia (a drug, either medicine or poison, later to be identified with written texts) anticipates the description of writing as a game, a playful pastime. But it also figures into the duality of games. Play might be nocuous, if it is performed in the wrong context and with regard to certain things; but seriousness isn't always appropriate either, even when it seems most natural (in philosophy and speech-making, for example). Like a drug, which might promote health or harm, play is good when it is morally appropriate, and only then. Seriousness, likewise, is not always the best way to approach a task.

In his explanation to Phaedrus regarding the reasons he does not rationalize myths (229c-230a), Socrates calls the pity-worthy intellectuals who do rationalize, boorish (agroikos). In Aristotle's Nicomachean Ethics, the person who possesses the virtue of wittiness or liveliness (eutrapelos) 6 lies between two extremes: the boorish (agroikos) and the buffoon (bomolochos). "Boorish" is a name for seriousness that is a vice. It is, both for Plato in the Phaedrus and for Aristotle in his Ethics, a trait that keeps a person from achieving virtue and happiness. ${ }^{7}$

Phaedrus is enthralled with the speech he is carrying because it suggests the erotic relationship is a game. He seems to think that Lysias is supremely clever and

\footnotetext{
${ }^{5}$ For the ongoing effect and importance of the scenery for the content of the dialogue, see Ferrari (1987), pp. 1-9, 21-34.

${ }^{6}$ NE 1108a24.

7 This does not suggest that Plato and Aristotle's views of playing are consistent; compare Aristotle's NE 1176b9-1177a12 with Plato's Laws 803c. See also Ardley (1967), pp. 228-9.
} 
sophisticated because the latter has managed to turn erotic attachments into something under the participants' control, making them players in a game in which they can either win or lose (Lysias is actually proposing a win-win situation). No more will men in love be subjected to desires which may ruin their lives. Lysias is describing a calculated transaction devoid of irrationality which will maximize the benefit of both parties. The detachment experienced in a game (as a clearly defined activity somewhat divorced from "real life") lets the beloved give his favors to the lover coolly and with a rational excuse. The lover, also, reaps his rewards in an emotionally detached way that does not present him as a love-crazy lunatic, who is prone to humiliate himself through his dedication to a boy. Lysias is proposing that love ought to be played as a game. As we will see in Socrates' critique of this speech, love cannot be a game. Moreover, those who claim it is one do so only to manipulate and take advantage of the desired, socially disadvantaged party.

Phaedrus reads Lysias' speech in what appears to be real sincerity. When he is finished, Socrates comments that he was positively "radiant" as he read (the name "Phaedrus" means "beaming", so Phaedrus is notably in his element with the speech). Socrates also admits that this probably means that Phaedrus understands more about these matters than he does, and that the marvelous effect the speech had on Phaedrus pulled Socrates himself to share in its madness. To this Phaedrus responds in a tone that might be read as both offended and reproachful: "Come, Socrates, do you think you should joke (paizein) about this?" (234d6). Socrates repeats the word for joke, homonymous with play, and replies with the question: "Do you really think I am joking, that I am not serious?". It is fair to assume that there is truth in Phaedrus' comment. Obviously Socrates is not truly impressed by the speech (as will be made abundantly clear in the second half of the dialogue), in terms of content or style. Phaedrus' offence at Socrates' remark is probably well deserved, and the use of the word paizein serves as a clue to what Socrates finds fit to make fun of and what not. 
Phaedrus demands Socrates be serious, and Socrates complies insofar as he gives his consistent, expected and pejorative opinion of Lysias' speech. Moreover, in this short interlude between the reading of Lysias' speech and Socrates' own first creation, the interlocutors set ground rules for what can only be regarded as a playful contest or a game. Socrates challenges the read speech and offers to make his own, which will prove superior. ${ }^{8}$ Phaedrus is excited at the prospect of a new speech; he is quite ready to retract his loyalty to Lysias' speech, which he admired so ardently just moments ago, in order to hear a new speech with new and exciting arguments. For him, the truth of the arguments and their moral implications are marginal at best; all he cares for is the performance of the game. Socrates sets his ground rules: he is allowed to repeat some of Lysias' points which he deems relevant (even the worst author hits on a good point by chance, so such a point can't be denied from his opponent). He will also retain the main aim of the argument, i.e. that the young man should give himself to a non-lover rather than a lover. Phaedrus readily agrees, and is elated by this rhetorical showdown. He is content with a speech being a gameperformance. Socrates, as we will see later on, can't be similarly content. But whether he disapproves, on the whole, of treating speech-making or philosophy as a game remains to be seen.

After the rules are set and Phaedrus has agreed to Socrates' concessions (235c236b), Socrates seems to have a change of heart. "Oh, Phaedrus, I was only criticizing your beloved (sou ton paidikon) in order to tease (ereschelon) you - did you take me seriously?" (236b4-5). With a threat of violence and a promise not to read to him ever again if he refuses to play his part, Phaedrus convinces his elder to commence with his speech.

Socrates gives his first speech with his head covered for shame. He tells a story that could be read as a myth (the Greek muthos is indeed a word for "story" as well as

\footnotetext{
8 See Plass (1967), pp.345-6.
} 
what we call myth today). "Once upon a time there was a fair boy..." , he begins, and goes on to justify the young man's preference of a non-lover over a lover. As he himself will show at length later on, his speech surpasses Lysias' in terms of rhetorical skill. But it is Socrates' inability to stop making speeches after he had fulfilled his commitment to Phaedrus that indicates that playing a game does not mean that the players are in an alternate reality where morality doesn't apply. On the contrary, playing ought to have a strong affinity to real life, especially in terms of morality. Games can be left or right handed; Lysias played a left-handed game because he left his speech as it was, complete with a morally reprehensible conclusion. Socrates gave a speech which shared that conclusion, but amended it later on with his Palinode, making his game a right-handed one.

Socrates' first speech initially seemed to stem from his participation in a game with Phaedrus. Socrates entered an agon (contest, show of excellence); he challenged Phaedrus and Lysias within the framework of their own conception of arete. Rhetoric, as defined in the Gorgias, is first and foremost a craft of persuasion. It is a way to use words effectively in order to gain as much power as possible -- such as the favors of an attractive young man, for instance. This common conception of rhetoric, which is only superficially rational (insofar as it follows logical rules but is amoral), is denounced by Socrates in the Gorgias as a knack which will never be a legitimate techne (Gorgias 462b-c). In the Phaedrus, though, rhetoric does get philosophical approval - but only thanks to Socrates' deviation from the game he and Phaedrus had agreed upon and his insistence on giving a second speech which is morally viable. The moral value of his second speech is identified with its positive relation to truth. This is the reason why the popular concept of rhetoric (which has no necessary tie to knowledge and truth, Phaedr. 259e6-260a4) may never be taken seriously. It is definitively a game, in the pejorative sense. Philosophy (and with it a philosophical concept of rhetoric, understood as soul-leading) might indeed prove to be a "serious"

\footnotetext{
9 Translated by Benjamin Jowett.
} 
enterprise, at least as serious as human activity can get. But it is important to note that Plato will insist on treating many aspects and expressions of philosophy, the ideally serious activity, as a right-handed game. This allows the philosopher an attitude of positive playfulness which enables sincere activity that doesn't take itself paralyzingly seriously.

When Socrates is done with the second speech, he and Phaedrus agree that they should discuss what makes speech-writing and speaking shameful or bad (258de). Socrates is quick to point out that the goodness of the speech must hinge upon its relation to the truth $(259 \mathrm{e})$. Rhetoric, though, has no necessary tie with truth. Therefore it is not really to be called an art (260e). But rhetoric is a practice which poses as a craft, and since it has to do with discourse and arguments, and often discusses the just and the noble, it is similar to philosophy. Again, it turns out that common rhetoric and philosophy are the left and right handed versions of speaking and writing. An important part of the differentiation between the two has to do with the way their practitioners view the practices themselves -- whether as serious actions or as play (and in what contexts each is regarded as one or the other). That is, when common rhetoric treats talking about issues such as justice and the good as roleplaying in an arena, and the orator as an actor who can act on behalf of justice and injustice equally without qualms (taking the whole situation to be a game) -- it is a problem. When Socrates the philosopher teases Phaedrus about his infatuation with Lysias and a worthless thing like the parchment he carries -- it is appropriate. The final discussion of writing and philosophizing will show that a genuine philosopher may be both playful and serious, in different contexts and with different people, and while acting in different ways (writing or speaking).

Socrates opens his evaluation of the three speeches given in the first half of the dialogue with these words: “... by some chance the two speeches do, as it seems, contain an example of the way in which someone who knows the truth can toy (prospaizon) with his audience and mislead them." (262c10-d2). The first quandary this 
sentence presents has to do with the identities of the two speeches Socrates is referring to. Are they Lysias' speech and his own first, which shared a premise and competed under the same rules? Or are they only his own two speeches? Or perhaps all three -- counting Lysias' speech as one and both of Socrates' speeches as one?

In the rhetorical analysis that follows, all three speeches are taken into account. Moreover, evidence in $263 \mathrm{~d} 3,265 \mathrm{c} 5,265 \mathrm{~d} 7$ and $266 \mathrm{a} 3$ all point to Socrates' perception of his two speeches as one ${ }^{10}$. He notes that his speech began with a definition of love, moving from censure to praise, retaining the initial premise that love is madness. Socrates also presents the famous image of speech as a living thing, with the proper place for each organ and natural joints - and gives his own as an example of a living creature with a left and right side (i.e., his first speech and the Palinode). So the two speeches Socrates refers to are most likely Lysias' speech and his own two speeches taken as one.

But then why would Socrates concede that both speeches were given by someone who knows the truth? It seems improbable that Socrates is suggesting that Lysias knows the truth about the general nature of love, madness, or the proper forming of speeches. But Lysias does hold an important truth which he keeps from his audience and Socrates openly reveals in the beginning of his first speech -- that the speech-maker is actually in love with the boy. The so-called "non-lover" is an impossible creature, a logical fallacy. Why would a person not in love (or in some way erotically infatuated) try to win someone's favors? As Socrates clearly puts it in the very short prologue to his first speech: "There was once a boy, a youth rather, and he was very beautiful, and had very many lovers. One of them was wily and had persuaded him that he was not in love, though he loved the lad no less than the others..." (237b2-4). So Lysias' access to truth, which allows him to mislead and "play" with his audience, has to do with his privileged access to the true motives of the person on whose behalf he is speaking. Socrates' privileged access to truth is

10 See also de Vries (1969), p. 206. 
much deeper than that -- not only does he understand the motives and wishes of his speaker and audience, he also knows the art of speaking (or at least he was endowed with momentary knowledge of it by the Muses, $262 \mathrm{~d} 2-5)$, and the value of the things he discusses.

So knowledge of truth allows speakers to use speeches in order to toy or play with their listeners. On the face of it, playing with listeners sounds like a bad thing to do. But Socrates is quick to clarify that this is not necessarily the case. He describes his speech thus: "We used a certain sort of image to describe love's passion; perhaps it had a measure of truth in it, though it may also have led us astray. And having whipped up a not altogether implausible speech, we sang playfully (prosepaisamen), but also appropriately and respectfully, a story-like hymn (muthikon tina humnon) to my master and yours..." (265b6-c2). There is an element of truth even in playful myths (or stories). As Socrates goes on to explain: “... everything else in [the speech] really does appear to me to have been spoken in play (paidiai). But part of it was given with Fortune's guidance, and there were in it two kinds of things the nature of which it would be quite wonderful to grasp by means of a systematic art." (265c8-d2).

This reference to play and storytelling serves a pivotal role in the structure of the dialogue. Socrates' words have a nuanced and careful tone to them: although it makes sense to dismiss such a playful story as the Palinode and seek truth in "serious" talk, this would be a mistake. The playful story has important lessons to teach us, Socrates advises, and it has a measure of truth alongside certain characteristics which may lead astray. These truthful insights, originating in the story, are worthy of systematic appreciation. And this is precisely the work cut out for the interlocutors in the second half of the dialogue. The grains of truth present in the myth are the link between the two parts of the text, and they represent the organic shift that ought to be made from playfulness to seriousness. The playful activity is the source and precursor of the more serious, systematic activity. It would be boorish of us to completely disregard the merits of the playful myth. It would be equally 
mistaken to be content with the myth as it is given and fall asleep to the lulling drone of the cicadas. This is what slaves, "sluggish of mind" (259a4), would do. The philosopher proceeds from play to seriousness, keeping in mind the playful origins of his discourse.

The ideas from the Palinode that are worthy of systematic understanding are: First, instating a clear definition of the subject matter as a first premise of the discussion; second, dividing the terms under discussion correctly and by their "natural joints". The first lesson of the speeches provides consistency. The second lesson is even more important: “... I am myself a lover of these divisions and collections, so that I may be able to think and to speak..." (266b3-4). The ability to divide correctly enables discourse itself. The rules of proper thought and speech are manifest in Socrates' mythical speech and in his dialogical discussion, and they govern both -- whether Socrates is possessed by the Muses and whether he is in his right mind. But it is important to remember that the Phaedrus is based entirely on these mad, playful speeches. The second half of the dialogue, which uses the speeches as a basis of discussion, must be therefore seen as somewhat playful, not completely serious.

This conclusion is strengthened by the end of the dialogue, where writing itself is described as play (277e-278b, to be discussed at length in the last section of this paper). The discussion of writing follows that of speaking, and begins with the myth of Theuth and Thamus. Socrates recounts a myth he claims the ancients told about Theuth, the inventor of writing, who is famous for the discovery of number, calculation, geometry, astronomy, and also games -- checkers and dice. He presents the invention of writing to the god-king Thamus, who censures it in the following way: "... [writing] will introduce forgetfulness into the soul of those who learn it: they will not practice using their memory because they will put their trust in writing, which is external and depends on signs that belong to others, instead of trying to remember from the inside, completely on their own. You have not discovered a 
potion (pharmakon) for remembering, but for reminding; you provide your students with the appearance of wisdom, not with its reality" (275a3-9).

Writing is a dangerous, deceptive thing. It puts in jeopardy the thing that ought to be our top priority, according to the Phaedrus' prologue: self-knowledge. Socrates warns that people who rely on writing will think they are wise when they are not, identifying with the external signs they study and failing to improve their own souls. This seems like a scathing condemnation of writing, until Socrates suggests that there is a "right-handed" version of it -- a "legitimate brother" (276a2). This is writing in the souls of listeners; a discourse that can answer back and defend itself when necessary, that knows when to speak up or be silent because it becomes an organic part of the soul in which it is written. The organic discourse living in the soul is an interesting concept. It embodies both the possibility of learning from outside resources and the importance of the soul's ability to harness its own innate (and dormant) knowledge, which serves as a canvas or soil.

The image of live discourse is one that once again raises the issue of seriousness and play. Socrates asks Phaedrus: "Would a sensible farmer, who cared about his seeds and wanted them to yield fruit, plant them in all seriousness in the garden of Adonis in the middle of the summer and enjoy watching them bear fruit within seven days? Or would he do this as an amusement (paidias) and in honor of the holiday, if he did it at all?" (276b1-4). Socrates goes on to claim that a serious man, who knows right from wrong, would not be serious about writing in ink. But he might just write anyway, as play (paidia, 276d2), making reminders of the truth for himself and those who wish to follow him. This will be the noble philosopher's preferred pastime. Phaedrus expounds Socrates' image thus: “Socrates, you are contrasting a vulgar amusement (faulen paidian) with the very noblest -- with the amusement of a man who can while away his time telling stories (muthologounta) of justice and the other matters you mentioned" (276e1-3). A philosopher's play is 
telling myths or stories of justice and the good, says Phaedrus, and Socrates couldn't agree more.

But play does not remain as the end of the story here. Socrates points at the serious: “... it is much nobler to be serious about these matters, and use the art of dialectic. The dialectician chooses a proper soul and plants and sows within it discourse accompanied by knowledge" (276e4-6). This wholly serious philosophical activity cannot do with written texts, which are mere images of spoken discourse; they also have nothing to do with mediocre interlocutors, whose souls are fickle and easily manipulated (like Phaedrus'). The upshot of Socrates' claim here is that the Phaedrus is not wholly serious, though it is definitely philosophical. Philosophy has both serious and playful manifestations. It is up to the reader and listener to determine which is which, and how to treat and make the most of each philosophical mode of discourse. The greatest danger, it seems, is to treat the playful as serious, or to dismiss the playful as philosophically (or "seriously") worthless. Socrates stresses that even the best written discourse is at most a reminder of knowledge. Being written, it is playful, but by virtue of the truth it reminds of, it has an element of seriousness. The point about written texts and suitable souls does not skip over the Phaedrus itself. As Socrate clearly says after the summation of his arguments about speaking and writing (277a8-278b3): “... our playful amusement regarding discourse is complete." (278b5).

\section{ii. myth and play}

As we have seen above, there are some clear textual links between play and myth in the Phaedrus (such as in 229c, 265c, 276e). But the Phaedrus is not the only dialogue in which these concepts are linked, and their connection can also be shown to exist independently. As Johan Huizinga writes in Homo Ludens:

Living myth knows no distinction between play and seriousness. Only when myth has become mythology, that is, literature, borne along as traditional lore by a culture which has in the meantime more or less outgrown the primitive imagination, only then will the contrast 
between play and seriousness apply to myth--and to its detriment. There is a curious intermediate phase, which the Greeks knew, when the myth is still sacred, and consequently ought to be serious, but is well understood to speak the language of the past [...] Hence in the period of their literary redaction myths, in order to be held in honour as sacred lore, must either suffer a mystical interpretation at the hands of priests or be cultivated purely as literature. To the degree that belief in the literal truth of the myth diminishes, the play-element, which had been proper to it from the beginning, will re-assert itself with increasing force. (pp. 129-130)

Huizinga's analysis is accurately embodied in Socrates' initial reference to myth in the Phaedrus' prologue (229c-230a). Socrates explains to Phaedrus the crossing-roads they have come to with regard to myth: On the one hand, no contemporary intellectual can take myths wholly seriously (as perhaps the "primitives" were supposed to have). On the other hand, being over-serious about them, as the miserable sophoi are, is boorish and equally mistaken. The right attitude toward myth, exhibited as the dialogue unfolds, is "re-assertion of the play-element" through the use and creation of myth. This is perhaps the reason Plato uses myths so readily throughout the dialogue, and also his pairing of myth with play. I suggest that the place of myth in Plato's Phaedrus can be explained and justified by his attitude toward play. In order to better understand this attitude, a brief overview of Plato's major references to the concept of play and its connection to myth in other dialogues will be given below.

The Laws has two approaches to play, which are somewhat separate: Play as a metaphor for our existence as humans, and play as a natural activity and educational tool for children. The former is expressed most clearly in Laws 803c, in which God is deemed the only thing worthy of seriousness. As products of the divine, humans are at best a plaything of God. Man's relation to the divine is the key to his chance at happiness and a virtuous life, and this too is put in terms of play: "So every man and every woman should play (paizonta) this part and order their whole life accordingly, engaging in the best possible pastimes (games, paidias)-- in a quite different frame of 
mind to the their present one [...] A man should spend his whole life at play-sacrificing, singing, dancing-- so that he can win the favor of the gods...".11 Referring to religious activities as play serves as an indirect invocation of myth. Myths are part and parcel of Greek religion, and they serve an important role in religious ceremonies and customs.

On the importance of children's games, Plato writes in two different sections of the Laws. One warns from the legislator's disregard of games children play (797a798d). Keeping an eye on the nature of children's games and preventing their frequent change is seen as highly important. Allowing children to change their gamerules, toys, and pleasures will result in adults who tolerate change even when it is for the worse, and a crude disrespect for tradition. Another mention of playing is more closely tied to children's educational program in the ideal state. In Laws 643b-d, the Athenian recommends children play with toys that resemble the tools of their future occupations: the little farmer-to-be should play with farming toys, the builder with toy houses, and so on. It is assumed that the navigation of the child toward toys and games that imitate his future activities will instill a habit of pleasure and attraction toward the particular set of skills for which he is already naturally predisposed, and cultivate greater stability and satisfaction in his adulthood.

The element of play is therefore present in Plato's philosophy of education (paideia). Another central element of education in Plato is the use of myth, or storytelling (this is a view of childhood that is commonsensical even today: it is seen as most natural and appropriate for children to play and listen to stories). In Republic 376e-377a Socrates presents an attitude toward myth that echoes that of the Phaedrus 265b7: “... we first tell stories (muthous) to children... These are false, on the whole, though they have some truth in them. And we tell them to small children before physical training begins". ${ }^{12}$ Socrates goes on to explain that educators must be

\footnotetext{
11 Translated by Trevor J. Saunders. Compare the Athenian's evaluation of the inversion of popular conception of social and moral order with Socrates' words in Gorgias 481b-482c.

12 Translated by G.M.A. Grube, revised by C.D.C. Reeve.
} 
extremely careful regarding the stories young children hear. Storytellers must be supervised and stories selected so that only the finest and most beautiful are chosen to shape the children's malleable souls.

Plato's use of the concept of play, especially when referring to the adult world, hinges on the common conception of the child as irrational and intellectually inferior. It is not by chance that in the Phaedrus, a dialogue where "play" comes up so often, a central theme is madness (i.e., irrationality) and its blessings. The myth of the Palinode explicitly connects irrationality and the blessing of philosophy. The image of the philosopher as an intellectually inferior child, who spends his day playing, is raised by Callicles in the Gorgias. "To partake of as much philosophy as your education (paideias) requires is an admirable thing, and it's not shameful to practice philosophy while you're a boy, but when you still do it after you've grown older and become a man, the thing gets to be ridiculous, Socrates!" (485a). ${ }^{13}$ Callicles goes on to explain that men philosophizing are playing (paizontas), and it doesn't fit their age or position. It is proper only for young children to philosophize, because philosophy is a form of play.

Callicles' remarks are not to be taken at face value, of course, but they are also not to be easily dismissed. What Plato is doing here with the concept of play is similar to what he did with it in the Laws, through the words of the wise Athenian quoted above (803c), and with the concept of madness in the Phaedrus. In all of these cases, Plato is taking on a term loaded with questionable characteristics. With "play", he must deal with the connotations of it being foolish, a waste of time, and unsuitable for rational adults. In the case of madness he is rediscovering a concept that invokes sickness and irrationality. Both play and madness are redeemed and presented as pertaining to philosophy at its best.

What we can learn from Callicles' mention of play in the Gorgias is that the battle against common negative interpretation of concepts is waged first and foremost

13 Translated by Donald J. Zeyl. 
with regard to philosophy itself. Philosophy is commonly seen as the left-handed use of words, no better or even worst than sophistry -- making the weaker claim stronger (as it is put in the Apology 18c). Philosophy is the practice regarded as what corrupts the youth, according to Socrates' trial, and the philosopher is an anti-educator. This is congruent with Callicles' opinion of philosophy. Plato sees it as the best thing a man can spend his days doing; Callicles believes it's only suitable for a child. The former sees it as the peak of rational thought, the latter as the mark of an infantile mind.This common opinion may be false, according to Plato, but it certainly ought to be taken into account and dealt with. Only through dialectical examination of preconceived opinions can any philosophical progress be made.

It is often the case that the opinions about philosophy and the philosopher's work which rise out of a dialogue's argument are diametrically opposed to the common notion (e.g., Gorgias 521d-e). This is not to say that Callicles' invocation of play in his rant against Socrates is a clear-cut approbation of play by Plato. But it might be the case that play is presented as a concept which is commonsensically adjunct to philosophy, and that Plato might not necessarily regard this as something negative; only that the pejorative opinion of play should be amended (as was done with regard to madness in the opening remarks of the Palinode).

Here, once more, the concepts of myth and play find themselves in similar positions. In the prologue of the Phaedrus, Socrates is asked whether he believes the story of Boreas and Oreithyia is true. Socrates gives a complex answer (in the passage referred to above, 229c-230a), from which it is unclear whether he does accept myths as true or not. Phaedrus' question implied a dichotomy between two mutually exclusive statuses: true and false. Socrates' ambiguous and evasive answer ("I have no time for such things...", 229e6) is congruent with his use of myth throughout the rest of the dialogue: he maintains myth as a vehicle for grains of truth, and awards his myths the attention they deserve via complementary dialectical analysis. Plato's use of myth, and the complexity and beauty of the the myths he produces, is evidence for 
his acceptance of their indispensability in the human philosophical enterprise. Use of myth is a presented as a natural part of the philosopher's approach to the world. ${ }^{14}$ This acceptance is paralleled to the appreciation of philosophy as play. Obviously, seriousness is a quality which philosophy genuinely aspires to; but it is dangerous to convince oneself that a human occupation, not a divine one, can ever be wholly serious. There is always an element of play in human activity, by virtue of the actor's humanity; and for the same reason, there will always be a mythical element in human discourse.

\section{iii. play, myth, writing and truth}

One of the most important characteristics common to play, myth, and writing is their capacity to intuitively qualify whatever they are referring to. Calling something playful or a game makes it seem less important, somewhat unreliable and with an uncertain truth-value. The same goes for myth. By labeling something a myth, other than a fact, a grounded opinion, or even just a common opinion, it is automatically qualified. In the final pages of the Phaedrus, Plato is claiming the same suspicion ought to be directed toward all written texts -- if something is written in ink, it is automatically inferior. And yet Socrates is often playful, he uses myth quite frequently, and Plato writes.

These three qualifying practices are all linked in the Phaedrus. Playing, mythmaking and writing all go hand in hand, and are immersed in the dialogue's most important aspects, both in content and form. Essentially, the qualifications impact the truth-status of the text. Plato suggests a series of tentative identities and propositions: writing is play; myth-making is play; myth has some truth in it; writing has some truth in it. Play can never be the "real thing", but it imitates and prepares for the true, serious practice (if it is right-handed play). Similarly, philosophy proper cannot be found in a text, and as a result, neither can truth be. Real philosophy and true ideas

\footnotetext{
${ }^{14}$ As Aristotle puts it:"... the myth-lover is in a sense a philosopher, since myths are composed of wonders", Metaphysics 1.982b (Translated by W.D. Ross, 1924).
} 
can be found only in a certain type of soul. In a written text there may be grains of truth, but never full-fledged or straightforward doctrines, clear-cut and unqualified. These grains can lead to real truth, but their truthfulness does not hold for the text as a whole. This goes for the mythical, story-like portions of the text, and also for the logical arguments and dialectical divisions-and-collections. It is often argued (see below) that there is more truth in Plato's logical arguments than in the myths. But according to the Phaedrus, it is important to remember that that is a discussion about which type of discourse is a lesser evil, which image is a closer resemblance of the real thing. Both are to be qualified; and each has different advantages to offer the philosopher. The myth holds grains of truth that are apparently the gifts of mad intuition, and might be difficult to come by in any other way. The dialectical argument mimics quite accurately the thinking-act of division and collection that the soul must practice in order to philosophize. But neither is philosophy proper.

Scholars such as Luc Brisson and Daniel Werner, who have written on the status of myth versus dialectic in Plato (and specifically in the Phaedrus), have consistently found myth to be the inferior mode of discourse and dialectic to be purely philosophical. Brisson writes: "Plato is so interested in myth because he wants to break its monopoly and impose instead a type of discourse he intends to develop, that is, the philosophical discourse for which he claims a superior status"15. The philosophical discourse Brisson is referring to is one based on arguments, propositions that have "verifiable status"16. Moreover, myth has no claim to truth at all: "A myth's truth value or lack of it is secondary only insofar as the myth is true or false according to whether or not it accords with the discourse conducted by the philosopher on the same subject. Why, then, try to transform the falsity of a myth into a truth? Truth must rather be sought where it lies, that is, in philosophical discourse" ${ }^{17}$

\footnotetext{
15 Brisson (1998), p. 87.

16 Brisson (2004), p. 25.

17 ibid, p. 27.
} 
Werner concurs with this evaluation: "...Plato does not use myth as a vehicle to express philosophical doctrines, and in fact does not even regard myth as capable of adequately expressing philosophical truths"18. Both commentators conceive dialectic, or argumentative discourse, as quite suitable for conveying philosophical ideas. But there is a cautionary note inherent in the connection Plato is making between myth, play and writing. This warning to the reader is echoed in Plato's chosen literary form, the dialogue (direct and narrated) ${ }^{19}$.

In any given dialogue, Plato freezes in time a specific situation, in a particular time and setting, with particular interlocutors. This literary choice addresses and underscores the problems and virtues of myth. A myth is an authorless logos with no clear authority but the culture of which it is a part. It can be easily undermined because of its historical or physical improbability and its reliance on the belief of its listeners. But this is similar to the case of Plato's dialogues. Did the young Socrates really converse with Parmenides and Zeno? Did the congregation of the famous Symposium really meet at Agathon's house and give those speeches? Are these questions philosophically relevant?

Plato assumes authorship over his dialogues in a complex manner, without inserting himself, as an author, into the specific grains of truth he is trying to convey in them. By putting the words in others' mouths, he is constantly undermining the readers' relentless desire to grant these truths his authority. This is why turning away from myth and looking at the dialectic discourse of the dialogues as a preferable or superior vehicle for truth-conveyance is problematic. It seems that Plato is signifying that the myth and the written, dialectic dialogue have much more in common than meets the eye. Both are playful, both of questionable authority. Each mode of discourse is qualified in a different way, but both are by nature qualified. It would benefit the readers of the dialogues, just like it would serve the listeners of myth, not

\footnotetext{
18 Werner (2012), p. 14.

${ }^{19}$ For a discussion of these issues, see Griswold (1988), pp. 66-83, 110-125.
} 
to dismiss the text (or parts of it) and not to take it at face value, but to consider it as a first step toward a philosophical discussion to be held within the soul.

\section{iv. conclusion}

The issue of play in Plato (and specifically in the Phaedrus) has not been written on extensively. And although it may be easier to consider Plato's myth-making as play ${ }^{20}$, it is not as intuitive to think of all types of discourse he presents, including dialectic, as such. In this paper, I argued that the importance of play in the Phaedrus has to do with the qualifications Plato wishes to impose on all sorts of philosophical discourses, among them both myth-making and written dialectic discussion.

The analysis of textual appearances of the word "play" in the dialogue pointed at two important and interconnected points: philosophy as it is presented in the Phaedrus is a form of right-handed play; myth-making and play are compatible and complementary. These two conclusions lead on to the idea that myth-making can indeed be seen as a vehicle for conveying philosophical truths. Truth may appear in myths to the same extent as it may appear in any other mode of discourse written by Plato. Its truth isn't straightforward, because it is playful; but any written discourse (including dialectical conversation) is playful, too. All of these playful activities, each in their own way, lead the soul of the listener or reader closer to undiluted truth (which isn't guaranteed to be accessed in this lifetime). Playfulness allows for the subtle interplay of simulation and creativity which are so important for the active philosopher.

Perhaps the most troubling question remains: Was this whole dialogue a game, an amusement? We certainly took it very seriously, it seems. And by taking it seriously, it appears we intended to find truths lying in plain sight in its words. The myths seemed like troublesome places to look for truths, as myths are naturally false

\footnotetext{
20 See Werner (2012), pp. 218-226. According to him the playfulness of the dialogue seems to be restricted to the un-philosophical myths, and the dialectic discussion deserves to be treated with all seriousness.
} 
in some way, being "just stories". So we turned to the dialectical discourse of the questions-and-answers. But we found that these exchanges are playful, too. By designating everything written as play, Plato has intentionally blurred the line between myth and dialectic. The result of this all-encompassing qualification is that the reader has their work cut out for them, in terms of reaching philosophical truths. The truth-lover's real work begins where the dialogue ends. And for readers of Plato, this conclusion makes sense -- it is actually quite familiar.

\section{bibliography}

All translations of Plato from Plato: Complete Works. Edited by John M. Cooper (1997). Indianapolis/Cambridge: Hackett Publishing Company. Secondary Literature: ARDLEY, Gavin (1967). The Role of Play in the Philosophy of Plato. Philosophy, vol. 42, No. 161, pp. 226-244.

BRISSON, Luc (1998). Plato the Myth Maker. Translated by Gerald Naddaf. Chicago: University of Chicago Press.

BRISSON, Luc. (2004). How Philosophers Saved Myths: Allegorical Interpretation and Classical Mythology. Translated by Catherine Tihanyi. Chicago: University of Chicago Press.

VRIES, G.J. de (1969). A Commentary on the Phaedrus of Plato. Amsterdam: Adolf M.Hakkert

FERRARI, G.R.F. (1987). Listening to the Cicadas: A Study of Plato's Phaedrus.

Cambridge: Cambridge University Press.

GILL, Mary Lousie (2012). Plato's Phaedrus: A Commentary for Greek Readers.

Norman: University of Oklahoma Press.

GRISWOLD, Charles L., Jr. (1986). Self-Knowledge in Plato's Phaedrus. New Haven: Yale University Press.

GRISWOLD, Charles L., Jr.. ed.(1988). Platonic Writings, Platonic Readings. New York: Routledge.

HUIZINGA, Johan (1950). Homo Ludens. New York: Roy Publishing. PLASS, Paul (1967). "Play" and Philosophic Detachment in Plato. Transactions and Proceedings of the American Philological Association, vol. 98, pp. 343-364. WERNER, Daniel S. (2012). Myth and Philosophy in Plato's Phaedrus. Cambridge: Cambridge University Press. 